Research article

\title{
Coping with earthquakes and COVID-19: A perspective of customer relationship management
}

Karen L. Orengo-Serra*

Professor, Graduate School of Business Administration, University of Puerto Rico, Rio Piedras, Puerto Rico.

karenl.orengo@upr.edu

María Sánchez-Jauregui

Research Assistant, Graduate School of Business Administration, University of Puerto Rico, Rio Piedras, Puerto Rico.

maria.sanchezjauregu@upr.edu

\begin{abstract}
This study describes Customer Relationship Management (CRM) resiliency activities carried out in Puerto Rico by small and mediumsized enterprises (SMEs) during a series of earthquakes and the COVID-19 pandemic. The objective of the study is to provide strategies to help businesses move forward and cope with negative effects of unexpected disruptive events. The data gathering process comprised 121 firms surveyed and 7 in-depth interviews with business owners and managers operating in Puerto Rico. Results reveal that reinforcing customer communications, followed by distribution and logistics re-engineering were some of the CRM resilience strategies frequently used by SMEs. By backing up their Critical Infrastructure (CI), businesses avoid telecommunications interruptions and stay in communication with stakeholders mainly via satellite and mobile Wi-Fi connections.
\end{abstract}

Keywords: customer relationship management; resiliency; Puerto Rico; COVID-19; earthquakes.

\section{Afrontando terremotos y COVID-19: una perspectiva de gestión de la relación con el cliente}

Resumen

Este estudio describe las actividades de resiliencia de la Gestión de la Relación con el Cliente o CRM, por sus siglas en inglés, llevadas a cabo en Puerto Rico por las pequeñas y medianas empresas (Pymes) durante una serie de terremotos y la pandemia del COVID-19. El objetivo del estudio es brindar estrategias para ayudar a las empresas a que avancen y manejen efectos negativos de eventos disruptivos inesperados. El proceso de recopilación de datos consistió en 121 encuestados y 7 entrevistas con dueños y gerentes de negocios que operan en Puerto Rico. El refuerzo de las comunicaciones con los clientes, seguido de la reingeniería de la distribución y logística, fueron algunas estrategias de resiliencia de CRM utilizadas con frecuencia. Con un respaldo en Infraestructura Crítica (IC) las empresas evitan interrupciones de las telecomunicaciones manteniéndose en comunicación con los constituyentes principalmente a través de las conexiones vía satélite y Wi-Fi.

Palabras clave: gestión de la relación con el cliente; resiliencia; Puerto Rico; COVID-19; terremotos.

\section{Lidando com terremotos e COVID-19: uma perspectiva da gestão do relacionamento com o cliente}

Resumo

Este estudo descreve as atividades de resiliência de Gestão do Relacionamento com o Cliente ou CRM, realizadas em Porto Rico por Pequenas e Médias Empresas (PMEs) durante uma série de terremotos e a pandemia COVID. 0 objetivo do estudo é fornecer estratégias para ajudar as empresas a avançar e gerenciar os efeitos negativos de eventos perturbadores inesperados. 0 processo de coleta de dados consistiu em 121 pessoas pesquisadas e 7 entrevistas com proprietários de empresas e gerentes que operam em Porto Rico. 0 fortalecimento da comunicação com o cliente, seguido pela reengenharia de distribuiccão e logística, foram algumas estratégias de resiliência de CRM usadas com frequência. Com suporte em Infraestrutura Crítica (IC), as empresas evitam interrupções nas telecomunicações, mantendo a comunicação com os constituintes principalmente por meio de conexões via satélite e wifi.

Palavras-chave: gestão do relacionamento com o cliente; resiliência; Porto Rico; COVID-19; terremotos.

*Corresponding author.

JEL classification: M1; M31; M39.

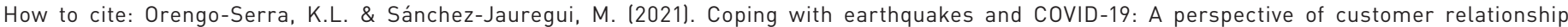
management. Estudios Gerenciales, 37(159), 318-331. https://doi.org/10.18046/j.estger.2021.159.4435

DOI: https://doi.org/10.18046/j.estger.2021.159.4435

Received: 16-oct-2020

Accepted: 23-apr-2021

Available on line: 18-jun-2021 


\section{Introduction}

Every year, businesses are impacted by disruptive events, which has motivated them to reformulate management strategies to mitigate the negative effects of these events and take advantage of the opportunities presented (Morrish \& Jones, 2019). Around 400 natural disasters and 40 armed conflicts occur worldwide each year (Waldman, 2019). Together, these and other disruptive events imperil the survival of businesses. Disruptions caused by natural events such as hurricanes, earthquakes, and pandemics, or human acts such as terrorism, sabotage, and technology (e.g., cyber-attack) threaten communities around the globe. Scientists predict that due to climatic change, the frequency and intensity of natural disasters will increase (USGS, n.d.), especially dangerous weather events in coastal areas. Another disruptive event that has caused economic and social disruption recently is the COVID-19 pandemic. International health experts agree that despite being rare, health pandemics will continue to occur; hence, the world should be prepared to cope with their effects (Donthu \& Gustafsson, 2020; World Health Organization, 2020).

Located in a zone highly vulnerable to natural disasters, Puerto Rico (PR) has experienced three major disruptive events since 2017: hurricane Maria, a series of earthquakes, and COVID-19. These events have aggravated its economic crisis and exposed its vulnerabilities in critical infrastructure and food dependence. Most recently, a series of earthquakes caused severe material damages in which approximately 300 homes were destroyed and two-thirds of the island population was left without electric power. Commercial infrastructure collapsed or remained in unsafe conditions, forcing many businesses to close or relocate their facilities to other municipalities. Van Der Elst, Hardebeck and Michael (2020) reported that aftershocks are expected to persist for years to decades; they stated that the probability of having a magnitude 6 or greater earthquake within a given year, going forward, will not fall below 25 percent for another 3 months to 3 years, and the risk of having a magnitude 5 or greater earthquake will not fall below 25 percent for a decade or more. In countries constantly exposed to earthquakes, businesses are often displaced and cyclically need to reinvent their operations to meet customer demand (Kay et al., 2019).

A few weeks after the 6.4 magnitude earthquake in PR, the COVID-19 pandemic outbreak reached the U.S. and spread to the island. According to the U.S. Centers for Disease Control and Prevention (CDC), the COVID-19 risk is high in PR but is lower than in most parts of the U.S. Globally, long-term quarantine, lockdowns, and suspension of public and private activities have had a large and adverse impact on aggregate demand, especially on consumption and exports (Shen et al., 2020). The total shutdown of economic activities has led many businesses to the brink of bankruptcy, while others closed temporarily or laid off employees, increasing inequality and displacement of affected people in hotspots such as the Caribbean and Latin America (United Nations, 2020). These measures to contain COVID-19 have spread disrupted global supply chains of goods and services and reduced the demand for imports significantly, with small and mid-size enterprises (SMEs) being the most impacted sector (Organization for Economic Cooperation and Development, 2020). Thus, the COVID-19 pandemic has disrupted consumer habits, and advancements in technology have helped accommodate these changes (Sheth, 2020). As in many countries affected by COVID-19, in PR lockdown meant that the few businesses authorized to open never recovered to normal profit levels; about 95 percent of SMEs in Puerto Rico, that is, 43,000 private businesses that have less than 50 employees, have been impacted by COVID-19 (Ramos Segarra, 2020). Tourism, retail, and restaurant industries are the sectors most impacted by the ongoing pandemic, with 100,000 jobs lost from March to May 2020 (Ramos Segarra, 2020).

However, some businesses have taken advantage of these disruptive events by adopting a new business model, incorporating new product/service offerings, and reshaping operations and inputs. Other businesses relocated their operations and/or integrated innovations and technologies to satisfy the needs of customers and newcomers (Donthu \& Gustafsson, 2020; Kay et al., 2019). Disruptive events may generate dramatic changes in everyone's life, forcing the business community to face a quickly changing market environment. In this scenario, customer relationship management (CRM) allows firms to be flexible and adapt to new issues, embrace product or service innovation, meet the expectations of new customers, and develop new channels to communicate with customers (Kumar \& Reinartz, 2018). CRM is a marketing intelligence concept aimed at managing business strategies using a relational approach; it aims to increase customer satisfaction, retention, and loyalty and discover new business opportunities (Rahimi \& Berman, 2009; Wakabayashi \& Merzthal, 2015). Since technology plays a vital role in any CRM approach, when disruptive events such as earthquakes or pandemics occur, businesses rely on resiliency tools or strategies to cope and continue operations.

This study investigates how companies in PR adopted CRM resilience strategies to meet customer needs during the first five months of lockdown due to the COVID-19 pandemic and the earthquakes experienced before and during the pandemic. The data presented here were generated from 121 firms surveyed and 7 in-depth interviews with business owners and managers under a grant awarded by the Resiliency and Business Innovation $(\mathrm{RBI})^{1}$ project in early 2020 . The goal of this project was

1 The Resiliency and Business Innovation (RBI) Project is an Economic Development Agency (EDA) i6 grantee and part of the supported programs under the Puerto Rico Science, Technology and Research Trust (PRSTRT). The RBI specifically focuses on potential business development of concepts related to resilience due to disasters. 
to conduct case study research on successful innovative and resiliency practices adopted by companies in Puerto Rico that helped them cope with the earthquakes and COVID-19 and can be replicated or serve as a model of business disruptive event management practices.

Even though research has increasingly focused on business recovery and resilience measures after disruptive events, very few CRM studies have examined how disruptive events affect customer relationships during and after them. This study describes CRM resiliency activities carried out by SMEs during earthquakes and COVID-19 in an innovative manner, by providing strategies for businesses to move forward and cope with negative effects of unexpected disruptive events. From a theoretical perspective, this research contributes to the scarce literature on resilience CRM by being the first study using the resilience framework to consider effects of two different disruptive events on multisectoral businesses in an insular territory. It shows what marketing strategy companies can use to re-establish CRM programs during and after disruptive events. Prior studies present general company strategies after disruptive events, but none analyze how to develop strategies from the perspective of resilience CRM.

The paper will first examine research on the CRM literature and how customer relationships are affected during and after a disruptive event, followed by a methodology and results for the empirical study. Then, the discussion and conclusion are presented.

\section{Literature review}

Research has increasingly focused on business recovery following catastrophic events and examined the resilience measures of companies (Morrish \& Jones, 2019). However, few empirical or conceptual CRM investigations explore how customer relationships are affected during and after a disruptive event (Baker et al., 2015; Biggs et al., 2012; Miles et al., 2016). Also, few studies consider CRM resilience strategies used by companies as mitigation techniques.

CRM strategies focus on customer orientation in a constantly evolving environment (Javalgi et al., 2006), "selecting customers that a firm can most profitably serve and shaping interactions between a company and these customers. The goal is to optimize the current and future value of customers for the company" (Kumar \& Reinartz, 2018, p. 5). When disruptive events occur, the intersection between CRM and resilience is considered to assure business continuity and meet the new needs of customers (Liu \& Black, 2011). A disruptive event (glitch, disturbance, crisis, etc.) is an unintended, untoward situation that generates corporate risk (Folke et al., 2010). For affected firms, it is an exceptional, anomalous situation compared to everyday business. Natural disasters, sabotages, terrorism, and health pandemics are examples altering human lives and the financial and natural resources of the affected community (Baker, 2009).

Disruptive events pose challenges to long-term consumer relationships, leading companies to develop new strategies to reestablish their customer value. Shen et al. (2020) indicate that internal marketing is an essential component of a CRM strategy; it is defined as the way a company treats employees as internal customers to promote service quality and customer satisfaction, achieving long-term business benefits. From the perspective of entrepreneurial marketing, Miles et al. (2016) and Morrish \& Jones (2019) focus on resiliency in the context of natural disasters. The recent literature investigates business resiliency during the COVID-19 pandemic in terms of firm performance, financial impact, consumer behavior, and the role of innovation and technology (Albuquerque et al., 2020; Shen et al., 2020; Eggers, 2020; Gu et al., 2020). However, few studies approach COVID-19 from marketing, strategic management, or entrepreneurial perspectives (Liguori \& Pittz, 2020; Sheth, 2020; Wang et al., 2020). There is a research gap between marketing management strategies and resiliency to cope with these types of disruptive events. This is the first study approaching resilience from the perspective of CRM amid two different disruptive events and addressing managerial actions taken in response.

\subsection{CRM resilience strategies}

Creating new value propositions, reshaping products and services, and capitalizing on new business opportunities allows for resiliency while reinforcing customer communication, leading to survival. Based on prior research, five CRM resilience strategies are explained in Table 1.

\section{Methodology}

To obtain a comprehensive view of the phenomena at hand, combined qualitative and quantitative methods were employed. Resilience is seen as the entrepreneurial capability at individual level to adapt to new changes and the ability to recognize new business opportunities and move forward (Martinelli et al., 2018). Both interviews and surveys were developed based on the study objectives and a review of previous literature on marketing and customer relationship management and on entrepreneurial resilience. Both instruments consisted of an integrated structured set of questions approaching the following dimensions: demographics, effects of earthquakes and COVID-19 lockdown policies in business in terms of losses, and CRM strategies to maintain close relationships with customers and partners (table A1, Annexes). A total of 10 open-ended questions guided in-depth interviews, while 18 closed- 
ended dichotomous and ranking scale questions composed the questionnaire. Questions related to managerial strategies to maintain relationship with clients were guided by constructs developed by LozadaContreras, Orengo Serra, and Sánchez-Jauregui (2021).

In-depth interviews allowed researchers access knowledgeable informants to collect and analyze data and to acquire sufficient information to understand the complexities and subjectivity associated with a phenomenon, if investigators collect a justifiable number of participants, including more than one participant from each represented organization (Crick, 2020). To address the lack of participants in in-depth interviews due to the lockdown policies set by the government during the study period, an electronic survey method was employed. Survey methods provide a wide scope of phenomena by enlarging and deepening, with interviews, the understanding of the research enquiries. The aim of employing two methods in this study was to improve completeness by data triangulation (Hussein, 2009).

\subsection{Interview data-gathering and analysis process}

In qualitative research, the size, type, and strengths of the firm as well as the role of the informants within the firm and context inform the sample selection (Crick, 2020). Seven out of the fifteen firms contacted participated in this study: a retail bakery, an accounting firm, a cracker manufacturer, a tropical fruits and plants producer, a cosmetics manufacturer and two retail pharmacies. All interviewees were business owners. Phone calls and e-mails were the main tools used to set up conference call dates and virtual meetings. Interviews were conducted in June 2020 and lasted between thirty and forty minutes. All conference calls and virtual meetings were recorded after receiving approval from participants. Recordings were transcribed to verify if the information was faithful and accurate. The transcripts were compared with the notes taken. Coded information was classified and indexed based on the responses and the constructs used in the thematic design of the questions. Constant comparison between data provided by each informant helped compare different interviewees (Crick, 2020), providing more accurate results. A table matrix was used to organize and highlight the data in a systematic way (Groenland, 2014).

\subsection{Questionnaire survey data-gathering and analysis process}

Using convenience sampling, 1,428 questionnaires were distributed via e-mail. The administration of the survey took 4 weeks, until June 12, 2020. A total of 121 valid responses were received resulting in a response rate of 10.6 percent. Participants were business owners, managers, employees and professional consultants of SMEs operating in Puerto Rico. After gathering the results, the data were analyzed using Microsoft Excel and Minitab. After processing the data from the surveys, CRM resilience strategies responses were compared with the interviews findings. Because the survey was employed for completeness purposes, descriptive statistics guided the analysis.

Table 1. CRM resilience strategies definitions

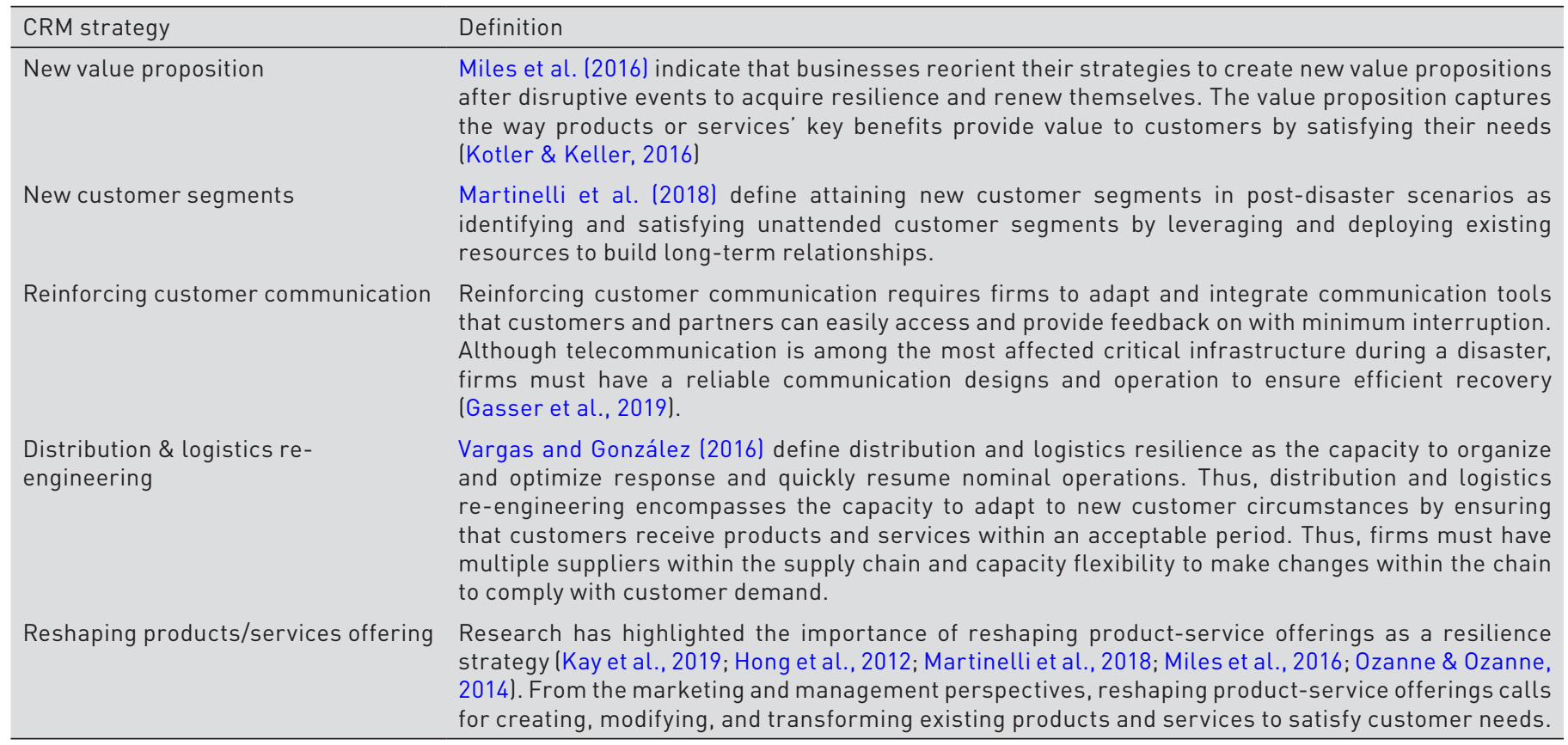

Source: own elaboration. 


\section{Results}

\subsection{Interview findings}

Out of the 7 firms participating in the interviews, one business operates in PR metropolitan area, and the remaining ones operate in the Southwest region of the island where earthquakes hit harder. These firms are in the manufacturing, retailing, and service sectors and are SMEs with 2-300 employees. The cracker manufacturer is a well-established firm engaged in business for many years compared with other firms, such as a local pharmacy that is relatively young loperating for little more than a yearl. After the 6.4 earthquake, a pharmacy was forced to relocate its business, while three firms reported minimal infrastructure damages. The remaining SMEs did not suffer any infrastructural damage. Hence, they quickly reopened, even though they experienced a slowdown in sales. The cosmetics manufacturer reported revenue losses, since sales stopped in the Southwest region. Its owner stated that "retailers in the Southwest region stopped buying our products as many consumers feared going shopping. Although some of our clients opened, there was no demand for our products. We had distribution problems because of the road collapse." Four out of seven participants affected by the earthquakes added services and products to their portfolio to meet customer demand. A summary of the resilience CRM practices implemented by interviewees is presented in Table A2 (Annexes).

In both disruptive events learthquakes and the pandemic), all SMEs used technology as a critical tool to strengthen customer relationships and process customer requests instantly. They relied on social media tools such as Facebook, e-mails, and phone calls to avoid business interruptions, reinforcing customer communications. They developed new competencies and tools to maintain constant communication with their customers by efficiently using all available communication channels.

The strict public policy implemented to deal with the COVID-19 pandemic in PR affected all interviewees. They had to rearrange business facilities, adjust business hours, reorganize distribution logistics, and implement new customer service protocols to comply with government restrictions. Three out of seven participants declared that their distribution and logistics changed significantly. Some providers stopped supplying to these businesses because they feared contagion as cases of COVID-19 proliferated around the island. A sample firm declared that they had to assume distribution tasks (functions) by collecting merchandise directly from the distributors' warehouse.

All interviewed firms changed their product offer to comply with health policies during the pandemic.
Reshaping product/service offers fosters the creativeness of businesses by modifying or adapting existing products or services to satisfy the expectations of new customers. The COVID-19 pandemic forced all participants to design and implement safety and health measures within their facilities. Moreover, they adapted their business model to take advantage of new business opportunities, representing a new value proposition for customers.

All interviewees expanded their product and service portfolios to satisfy new demands and target new customers. These strategies included offering delivery services, non-perishable food, and healthcare products. Two participants, a retailer and the cosmetic manufacturer, experienced national and regional sales growth during the pandemic. The retailer began supplying personal protective equipment (PPE) products such as gloves and face masks to businesses across the U.S.; in addition, they incorporated a new task within the distribution and logistics division by hiring drivers to collect merchandise from suppliers. Other participants declared that the distribution and logistics of goods from their suppliers remained stable. Meanwhile, the cosmetics manufacturer transferred production and sales personnel to perform distribution and logistics tasks during the pandemic. Thus, the SMEs transformed their daily operation activities to comply with new safety regulations and curfew policy. Transformability and adaptation are two vital features that enable firms to be resilient, flexible, and innovative (Folke et al., 2010). Transformability can create an alternative system when ecological, economic, or social structures make the existing system untenable (Folke et al., 2010). The interviewees successfully transformed and adapted their CRM activities under COVID-19 government restrictions.

\subsection{Survey participant responses}

A questionnaire survey was carried out on 121 SMEs, mainly located in the PR metropolitan area. Approximately 74 percent of the participants were the owner and/or president of their company. More than half of these firms operate in professional services, manufacturing, or medical/healthcare industries. Approximately 79 percent of these firms have less than 20 employees. This study found that between 6 and 49 percent of the interviewed firms had experienced critical infrastructure failures, such as electricity, water supply, and telecommunications, when the sequence of earthquakes struck offshore of southern PR. Luckily, 64 percent of the firms already had a backup power system, and 50 percent had a water reserve to keep operations running. Between 20 and 30 percent had neither telephone nor Internet access during these series of events. Around 25 percent suffered damage worth less than $\$ 25,000$ USD to their premises, equipment, inventory, vehicles, and/ 
or other infrastructure. Most firms located in the PR metropolitan and eastern areas did not suffer any property damages. However, approximately 40 percent had to temporarily close their operations, even if they reported no property damage or loss, as a safety measure. A few firms had to suspend their employees without pay due to their economic situation.

These results are in contrast with the findings from the COVID-19 pandemic. The study shows that, during the pandemic, 68 percent of firms temporarily closed their business due to strict government lockdown in PR. Almost half of the firms suspended their employees with no compensation. A few firms were forced to relocate their business, and others had to switch their daily operations to an online platform. Over 60 percent of the firms had to rely on Internet, mobile data, and phone to serve current and potential customers. Approximately 75 percent experienced monetary losses of less than $\$ 200,000$ USD from the pandemic.

Figure 2 illustrates the responses of participants regarding how much they agree or disagree with the implementation of CRM resilience strategies after a disruptive event. A total of 121 participants answered the survey about the earthquakes and pandemic separately, providing a total of 242 responses.

The survey results reveal that almost all participants implemented one or more CRM resilience strategies in response to the earthquakes and the COVID-19 pandemic.

\section{Discussion}

Businesses are resilient when they can react quickly (nimbly) to changes in demand and supply, adapt to changes in the environment, align to partners and customer interests, and identify new strategies and opportunities (Christopher \& Lee, 2004; Folke et al., 2010). The interviewed SMEs revealed that all firms experienced business process changes due to the earthquakes and the COVID-19 pandemic, forcing them to adopt new CRM activities. SMEs adjusted to changes in the external environment and hastened to adopt CRM resilience strategies to meet customer needs and retain their loyalty. These process changes provided firms with the opportunity to develop a new value proposition, identify new customer segments, and reshape product/service offerings. Product and service customization and customer service improvement across distribution channels are key CRM value drivers for the achievement of customer equity (Richards \& Jones, 2008). Facebook played a significant role in providing customer services, allowing customer contact during and after a natural disaster. The primary communication tools used by SMEs to reinforce customer relationships were social media, telephone, and e-mail. After the series of earthquakes, a retailer used social media and billboards located downtown to announce their business relocation and attract potential new customers. Business relocation could represent a connection loss with the community and customers but also implies an opportunity to reinvent the business and its image (Kay et al., 2019). Moreover, the performance of employees was crucial to the businesses success after the disruptive events. Two interviewees had polyvalent workers, which allowed the companies to transfer them to other operations needed to keep running the business.

A five-point Likert scale was proposed in the questionnaire to assign numerical values to participants attitudes, opinions, and perceptions regarding CRM resilience strategies: (1) Strongly disagree; (2) Somewhat disagree; (3) Do not agree nor disagree; (4) Somewhat agree; (5) Strongly agree. Table 2 describes the central tendency of the participant responses to CRM resilience strategy implementation using scores on the Likert scale.

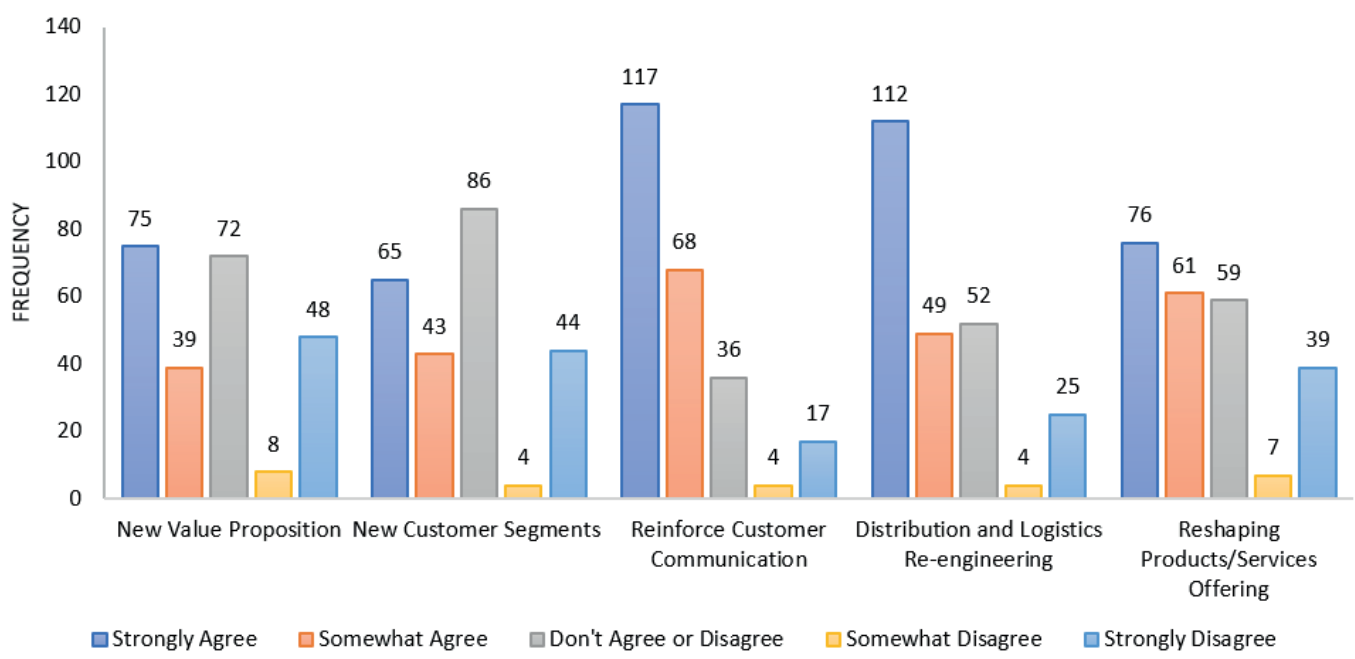

Figure 1. Participants' responses about CRM resilience strategies Source: own elaboration. 
Table 2. Descriptive statistics of the participants' responses

\begin{tabular}{|c|c|c|c|c|c|c|}
\hline Variable & Event & $\mathrm{N}$ & Mean & Median & Mode & $\begin{array}{l}\mathrm{N} \text { for } \\
\text { mode }\end{array}$ \\
\hline $\begin{array}{l}\text { New value } \\
\text { proposition }\end{array}$ & $\begin{array}{l}\text { Earth- } \\
\text { quakes } \\
\text { cOVID-19 }\end{array}$ & 121 & $\begin{array}{l}2.90 \\
3.80\end{array}$ & $\begin{array}{l}3.00 \\
4.00\end{array}$ & $\begin{array}{l}3 \\
5\end{array}$ & $\begin{array}{l}52 \\
57\end{array}$ \\
\hline $\begin{array}{l}\text { New customer } \\
\text { segments }\end{array}$ & $\begin{array}{l}\text { Earth- } \\
\text { quakes } \\
\text { cOVID-19 }\end{array}$ & 121 & $\begin{array}{l}2.90 \\
3.76\end{array}$ & $\begin{array}{l}3.00 \\
4.00\end{array}$ & $\begin{array}{l}3 \\
5\end{array}$ & $\begin{array}{l}57 \\
50\end{array}$ \\
\hline $\begin{array}{l}\text { Reinforce } \\
\text { customer } \\
\text { communications }\end{array}$ & $\begin{array}{l}\text { Earth- } \\
\text { quakes } \\
\text { covID-19 }\end{array}$ & 121 & $\begin{array}{l}3.79 \\
4.38\end{array}$ & $\begin{array}{l}4.00 \\
5.00\end{array}$ & $\begin{array}{l}5 \\
5\end{array}$ & $\begin{array}{l}43 \\
74\end{array}$ \\
\hline $\begin{array}{l}\text { Distribution and } \\
\text { logistics } \\
\text { re-engineering }\end{array}$ & $\begin{array}{l}\text { Earth- } \\
\text { quakes } \\
\text { COVID-19 }\end{array}$ & 121 & $\begin{array}{l}3.45 \\
4.35\end{array}$ & $\begin{array}{l}4.00 \\
5.00\end{array}$ & $\begin{array}{l}5 \\
5\end{array}$ & $\begin{array}{l}39 \\
73\end{array}$ \\
\hline $\begin{array}{l}\text { Reshaping } \\
\text { product/service } \\
\text { offerings }\end{array}$ & $\begin{array}{l}\text { Earth- } \\
\text { quakes } \\
\text { COVID-19 }\end{array}$ & 121 & $\begin{array}{l}3.00 \\
4.00\end{array}$ & $\begin{array}{l}3.00 \\
4.00\end{array}$ & $\begin{array}{l}3 \\
5\end{array}$ & $\begin{array}{l}42 \\
54\end{array}$ \\
\hline
\end{tabular}

Source: own elaboration.

The results in Table 2 show that reinforced customer communication and distribution and logistics reengineering scored the highest during the COVID-19 pandemic. Reinforced customer communication also has the highest number of responses (74), it is close to the second-highest strategy (73), and participants strongly agreed with the implementation of this strategy. Communication with relatives, government agencies, employees, partners, and clients plays an important role when addressing a disruptive event (Baker et al., 2015; Kay et al., 2019; Ozanne \& Ozanne, 2014). In the communication process, social media and Internet applications have been positioned as leading communications tools to carry out CRM activities (Kumar \& Reinartz, 2018). Social media platforms such as Instagram, Facebook, Twitter, and Linkedln have proven essential to gather information, connect with customers, grow brand recognition, and market new products.

For half of the CRM resilience strategies examined, interviewees either somewhat agreed (4) or strongly agreed (5), meaning they had a positive opinion regarding the implementation of these strategies during a disruptive event. The sum of the CRM resilience strategy scores was calculated, and Figure 2 illustrates the total score of each CRM strategy for the disruptive events.

Figure 2 shows that reinforcing customer communication is the most important CRM resilience strategy implemented by the SMEs in both disruptive events. Two-way communication with suppliers and customers is essential in the response and recovery period (Kay et al., 2019). Most firms minimized corporate losses by efficiently using communication channels, maintaining constant communication with their customers. The second most important CRM resilience strategy varied across events; when a series of earthquakes shook the southern coast of $P R$, firms positioned a new value proposition in consumer minds, enabling them to align to the needs of new customers. The development of marketing tools to address customer needs through a new value proposition is essential to mitigate the consequences of a disaster. According to Baker et al. (2015), these marketing tools are marketing exchange systems and involve a process in which two or more actors transfer valuable resources to satisfy the needs and desires of customers affected by a disruptive event.

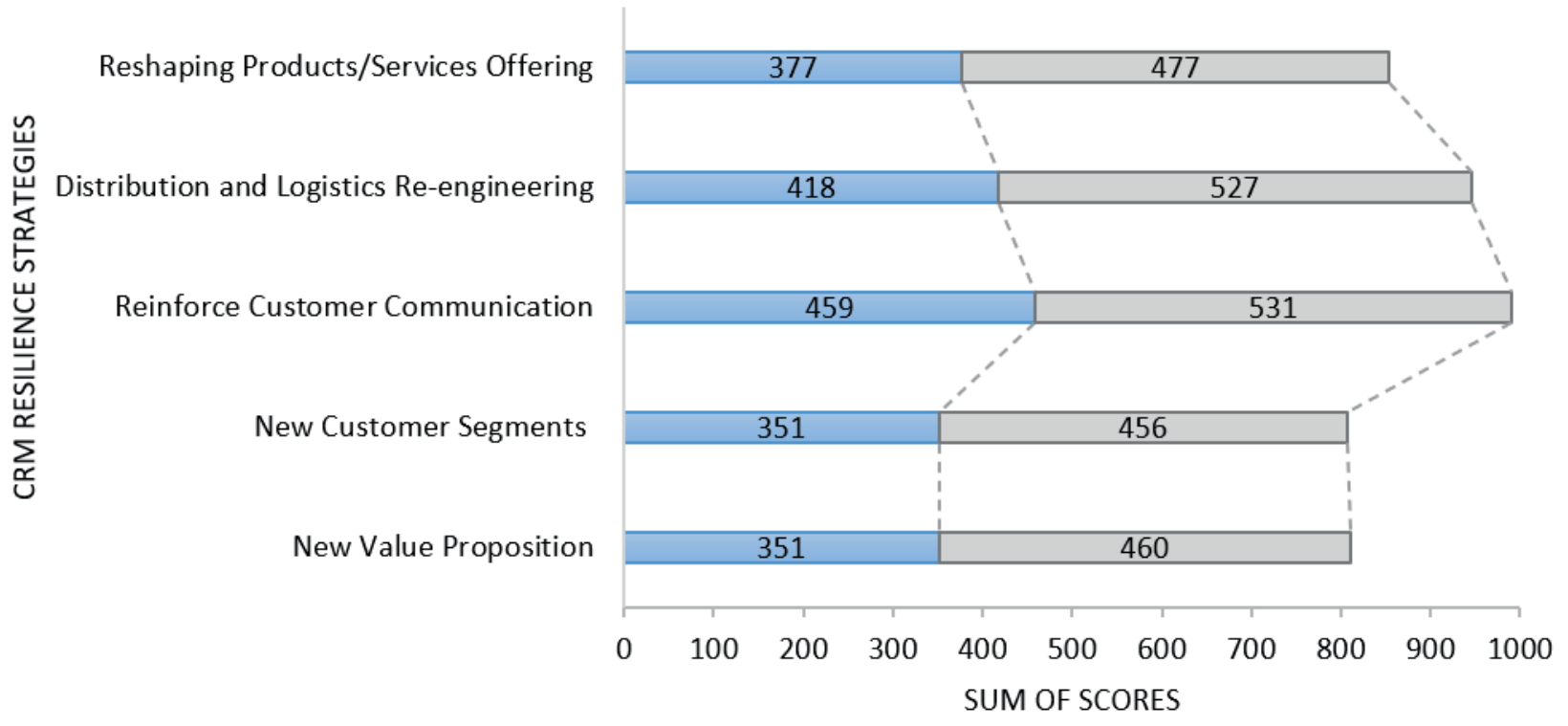

$\square$ Series of Earthquakes $\quad \square$ COVID-19 pandemic

Figure 2. Total score of the survey responses using a five-point Likert scale Source: own elaboration. 
The results of this study show that the third most important CRM resilience strategy in the pandemic is reshaping product/service offerings, but not in the case of an earthquake. During both disruptive events, we observed that some firms changed their existing products and/or services to satisfy the expectations of new customers. This finding is consistent with that of Anionwu et al. (2014), who found that the strategic adaptation of product variables during post-disaster marketing operations is likely to quicken recovery. Baker (2009) and Biggs et al. (2012) also found that businesses change their products and services after a natural disaster; however, in the event of an earthquake, identifying new customer segments seems more important than reshaping product/service offerings. Overall, the results of this study suggest that major disruptive events such as a natural catastrophe or a pandemic may positively or negatively impact the business processes of companies, temporarily or permanently. Some businesses took advantage to develop a new product and service portfolio or made incremental innovations at operational level to be aligned to the needs of new customers while reacting proactively to disruptive events. That included more personalized customer services - such as distribution and logistics management - and the intensive use of social media and other Internet platforms as communications tools.

\section{Conclusions}

Island territories are constantly under threat of disruptive events. Large-scale health outbreaks are atypical and rarely addressed by the business literature; however, this kind of disruption has implications in all aspects of society. The COVID-19 pandemic showed that countries are not prepared to cope with large-scale and long-term crises. Many global economies operate within extremely open international trade dynamics, they import goods and services from all over the world, thus limiting the integration of domestic providers. This is the case with Caribbean islands, which are net food importers ( $\mathrm{Ng}$ and Aksoy, 2008), highly vulnerable to disruptive events that may interrupt their daily operations (Pelling \& Uitto, 2001). The COVID-19 pandemic has forced businesses around the world to restructure their operations and organizational management and even consider permanent lockdowns, causing unprecedented inter ruptions in commerce and severely hitting the transportation, hospitality, and tourism sectors (Donthu \& Gustafsson, 2020; Shen et al., 2020; Sigala, 2020). The e-commerce of goods and services and last-generation apps experienced unexpected growth and demand (Donthu \& Gustafsson, 2020). COVID-19 provides an ideal context for marketing managers to understand how technology transforms wishes into needs, developing new habits in customers and family budgets, and merging old necessities (food, shelter, and clothing) with new ones (phone, Internet, and apps) (Sheth, 2020). By implementing marketing innovation strategies, Chinese firms responded to the rapidly changing consumption patterns of customers to survive and recover from the COVID-19 pandemic (Wang et al., 2020). Their reactions included intensive use of digital technologies such as e-commerce and social media platforms to reach customers confined at home, and the use of smartphones and computers to make purchases and communicate with the external environment (Wang et al., 2020).

Business resilience is crucial to mitigate and respond to disruptive events; CRM is a practical marketing and management tool for it. The concept of CRM has been widely discussed in the literature considering its importance in the marketing field (Ascarza et al., 2017; Cambra-Fierro et al., 2017; Debnath et al., 2016; Kotler \& Keller, 2016; Williams et al., 2017).

This study is one of the first attempts to address resilience from the CRM perspective. It shows that integrating CRM resilience strategies into the recovery process of a business is crucial. All interviewed firms agreed that implementing CRM strategies allowed them to restructure their day-to-day activities, seek new business opportunities inside and outside PR, expand their product/service portfolio, and reinforce customer communication to cope with the impact of both disruptive events. The results indicate that new value proposition, new customer segment, reinforcing customer communications, distribution and logistics re-engineering, and reshaping product/service offering are the most important CRM strategies to build a strong, resilient business.

Reinforcing customer communications was the most used CRM resilience strategy by SMEs in PR during and after the earthquakes and the COVID-19 pandemic. Nowadays, social media platforms have become a necessary tool for businesses to provide customer support, increase brand awareness, and reach out to potential customers. Companies interact with customers, monitor their brand, and gather data about customers in real time through social media platforms. These data enable firms to offer appropriate content and personalized messages to target customers, improving customer experience (Kumar \& Reinartz., 2018). The results of this study indicate that SMEs frequently used social media and the Internet to establish communication with stakeholders during disruptive events. During the COVID-19 pandemic, Internet applications became the main tools in hospitals worldwide to communicate with patients and medical staff and business providers (Back et al., 2020). The use of the Internet allowed businesses to reach customers and achieve sustainability during the pandemic (Sheth, 2020; Wang et al., 2020).

Another CRM resilience strategy often used by SMEs in PR was distribution and logistics re-engineering. This 
strategy allowed SMEs to exchange information fast to ascertain the latest situation le.g., levels of inventories and processes) of each link in their network. SMEs transformed their business process to acquire finished goods. A firm incorporated a distribution and logistics division within its business model by hiring drivers to collect merchandise from suppliers when a series of earthquakes struck the southern side of the island. Furthermore, reshaping product/service offering was the third most important CRM resilience strategy during the COVID-19 pandemic, but not in the case of the earthquakes; identifying new customer segments was more important in the event of an earthquake than reshaping product/service offering.

These findings coincide with the entrepreneurial marketing theoretical approaches used in the postdisaster recovery process described by Morrish and Jones (2019). In their study, entrepreneurial actions were taken to support businesses in a post-quake setting. These actions refer to opportunity-seeking behaviors, organizing resources (controlling rather than leveraging the company resources), creating customer value, and accepting risk. Risk-taking and collaborative innovations with business partners are marketing innovation strategies implemented by firms to cope with the COVID-19 pandemic and to take advantage of new business opportunities (Wang et al., 2020).

Building on the study findings, some practical recommendations are proposed for achieving business resiliency in the case of natural disasters and health pandemics. Some of these proposals concur with recent studies (Liguori \& Pittz, 2020; Pelling \& Uitto, 2001; Wang et al., 2020) and fill a research gap by providing recommendations to improve CRM systems. These suggestions are expected to allow businesses to move toward reliable and safe interaction with customers, for example via digital communication (Pantano et al., 2020), understanding new market needs, and providing goods and services by promoting collaboration with stakeholders, including them in the business process.

Businesses must have clean energy backup systems for critical infrastructure, as energy supply is very unreliable in countries that are heavily reliant on fossil fuel energy. This may apply in particular to businesses in the professional services, healthcare, and manufacturing industries, since they represented more than half of the surveyed and interviewed participants in this study. Backing up Critical Infrastructure (CI), e.g. power infrastructure, allow businesses to avoid telecommunications interruptions and stay close with customers and partners; the study revealed the intense use of the Internet, cell phones and social media platforms by participants. Cl support systems include satellite telecommunications, optical fiber for continuous internet access, telephony, and microgrid networks for renewable energy and industrial generators (Freeman \& Hancock, 2017). "Cl comprises systems and facilities that are vital to the security, economy, health, and safety of the public" (Freeman \& Hancock, 2017, p. 935). Backup in telecommunications, for example, allows firms to stay in communication with stakeholders via, for instance, satellite and mobile Wi-Fi connections (Forbes, 2009). In this endeavor, we suggest that businesses must have a satellite phone available as an element of strong telecommunications backup and must make sure that their suppliers have a satellite phone and/or other telecommunications backup too. Access to telecommunications lets businesses coordinate with their partners in the supply chain to ensure proper flow operations.

This study has implications for various contexts and target audiences. First, academics may provide training to SMEs based on the results, which may serve as the basis for future research focusing on economies similar to Puerto Rico's. The results may be of interest to policymakers and professional organizations. Finally, the study provides new insights to marketing managers to help them develop effective CRM resilience strategies in the event of a business interruption. At the same time, two main limitations arise from this research: constraints in recruiting more participant firms for the in-depth interviews, and the small number of survey respondents (10.6\%); the context in which data gathering was executed (country lockdown measures adopted by the government) made difficult to reach more firms to secure participation. Only phone calls and emails were the two main communications tools to reach them, and many of the SMEs were operating on an irregular basis and with limited number of employees authorized to return to work. Despite these limitations, we captured new insights never before explored about this phenomenon and how CRM became an important management resilience tool to cope with disruptive events. On the other hand, understanding consumer behavior within this context remains as an important subject for future studies. For instance, assessing consumer behavior reactions vis-à-vis firms under two different disruptive events, such as a natural catastrophe and health pandemic, could be suggested as a future line of research.

\section{Conflict of interest}

The authors declare that they have no conflict of interest.

\section{Acknowledgment}

This work would not have been possible without the financial support of the Resiliency and Business Innovation (RBI) Program, an Economic Development Agency (EDA) i6 grantee and part of the supported programs under the Puerto Rico Science, Technology and Research Trust (PRSTRT). We are grateful to all the SMEs in Puerto Rico, who have taken their time to participate in the interviews and/or surveys conducted for this research. 


\section{Annexes}

Table A1. Electronic Survey Questions

\begin{tabular}{|c|c|c|c|}
\hline \multicolumn{2}{|c|}{ Q1: Which of the following best describes your position in the company? } & \multicolumn{2}{|c|}{ Q4: What is your organization's primary business activity? } \\
\hline 89 responses & Owner or President & 42 responses & Professional Services \\
\hline 14 responses & Manager or Supervisor & 16 responses & Manufacturing \\
\hline 5 responses & Professional Services & 14 responses & Retail \\
\hline 4 responses & Employee & 14 responses & Hospitality, Restaurants and Tourism \\
\hline 60 responses & Female & 4 responses & Wholesale \\
\hline \multicolumn{2}{|c|}{ Q3: Location of the business in Puerto Rico } & \multicolumn{2}{|c|}{ Q5: How many people are employed? } \\
\hline 56 responses & Metro & 95 responses & 1 to 20 employees \\
\hline 21 responses & East & 13 responses & 21 to 50 employees \\
\hline \multicolumn{4}{|c|}{ Series of Earthquake 2019} \\
\hline \multicolumn{2}{|c|}{$\begin{array}{l}\text { Q6: What were the business damages, needs or losses during and after } \\
\text { the earthquakes that occurred between Dec } 2019 \text { and Jan 2020? }\end{array}$} & \multicolumn{2}{|c|}{$\begin{array}{l}\text { Q9: Does the business or company have an energy backup system } \\
\text { (for example, photovoltaic system, battery system and /or generator, } \\
\text { among others)? }\end{array}$} \\
\hline 59 responses & Interruption of electric power & 77 responses & Yes \\
\hline 49 responses & Temporary or permanent closure of the business & 44 responses & No \\
\hline 44 responses & No damages, needs or losses & \multicolumn{2}{|c|}{$\begin{array}{l}\text { Q10: If you selected "Interruption of water supply" in question 6, how } \\
\text { long did it take to restore the system in the business or company? }\end{array}$} \\
\hline 29 responses & Interruption of telecommunications & 3 responses & Less than a day \\
\hline 14 responses & $\begin{array}{l}\text { Damage or loss of inventory, raw materials and/or } \\
\text { packaging }\end{array}$ & 8 responses & 1 to 6 days \\
\hline 2 responses & Damage or loss of machinery and/or company vehicles & 59 responses & No \\
\hline 1 response & Severe infrastructure damage greater than $\$ 50,000$ & \multicolumn{2}{|c|}{$\begin{array}{l}\text { Q12: If you selected "Interruption of telecommunications" in question } \\
6 \text {, how long did it take to restore the system in the business or } \\
\text { company? }\end{array}$} \\
\hline 1 response & Voluntary or forced relocation of the business & 8 responses & Less than a day \\
\hline \multicolumn{2}{|c|}{$\begin{array}{l}\text { Q7: If you selected "Interruption of electric power" in question 6, how } \\
\text { long did it take to restore the system in the business or company? }\end{array}$} & 24 responses & 1 to 6 days \\
\hline 12 & Less than a day & 3 responses & 1 to 2 weeks \\
\hline 39 responses & 1 to 6 days & 2 responses & More than a month \\
\hline 6 responses & 1 to 2 weeks & 84 responses & Not applicable \\
\hline 7 responses & 3 to 4 weeks & \multicolumn{2}{|c|}{$\begin{array}{l}\text { Q13: During the earthquakes, what telecommunication services } \\
\text { were NOT available? }\end{array}$} \\
\hline 2 responses & More than a month & 24 responses & Telephone \\
\hline 55 responses & Not applicable & 9 responses & Cable \\
\hline \multicolumn{2}{|c|}{$\begin{array}{l}\text { Q8: Estimated value of the damage to the premises, equipment, } \\
\text { inventory, vehicle, or other }\end{array}$} & 35 responses & Internet \\
\hline 30 responses & Less than $\$ 25,000$ & 5 responses & Mobile (cellphone data, hotspot and/or calls) \\
\hline 10 responses & $\$ 25,001$ to $\$ 50,000$ & 81 responses & Not applicable \\
\hline
\end{tabular}


Table A1. Electronic Survey Questions (continuation)

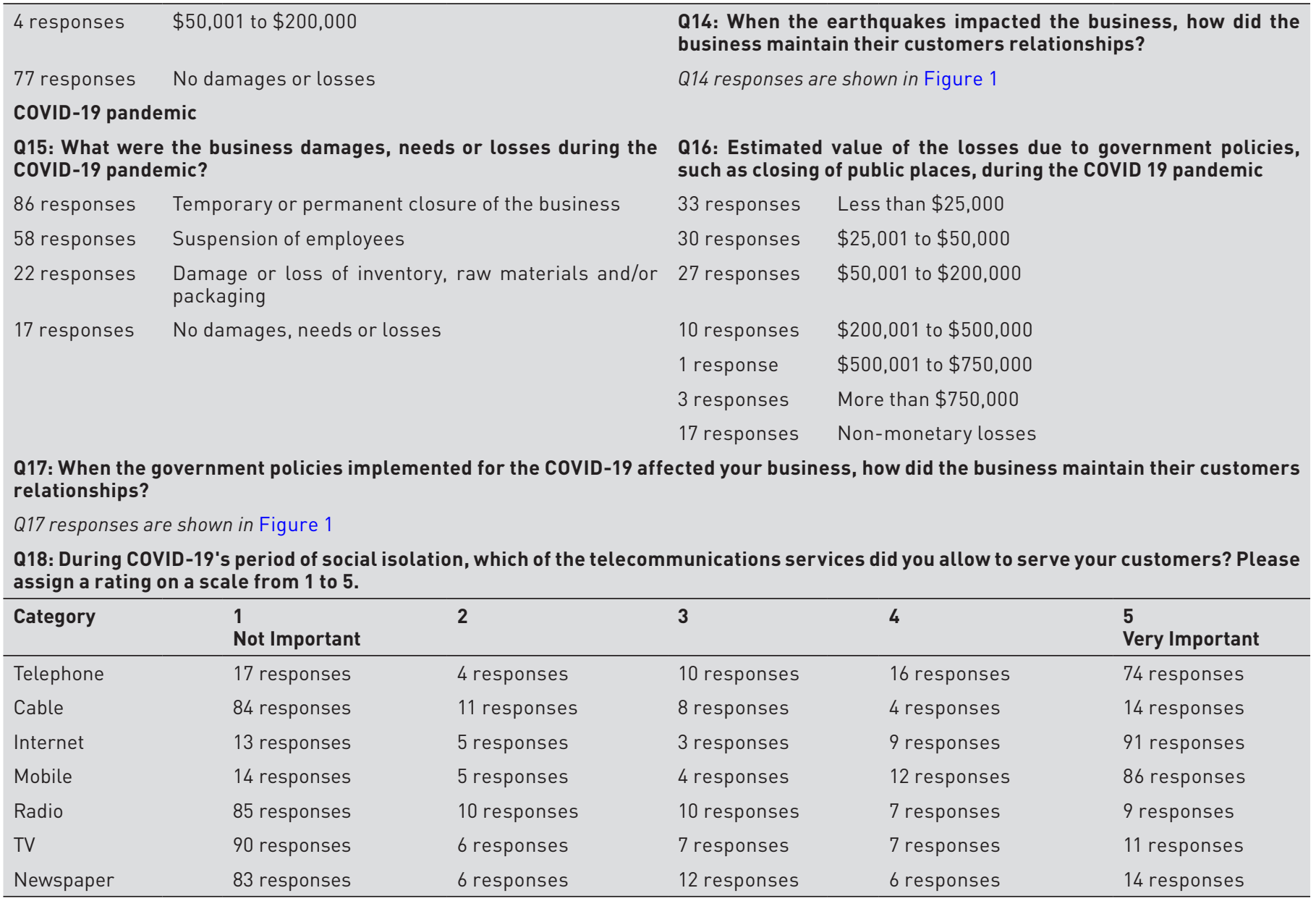

Source: own elaboration.

Table A2. Interview responses summary: resilience CRM matrix

\begin{tabular}{|c|c|c|c|c|c|c|c|}
\hline \multirow[t]{2}{*}{ SMEs } & \multicolumn{5}{|c|}{ Contingency CRM resilience construct matrix in-depth interviews } & \multicolumn{2}{|c|}{ Effects } \\
\hline & New Value Proposition & $\begin{array}{l}\text { New customer } \\
\text { segments }\end{array}$ & $\begin{array}{l}\text { Reinforcing } \\
\text { customer } \\
\text { communications }\end{array}$ & $\begin{array}{l}\text { Distribution and logistics } \\
\text { re-engineering }\end{array}$ & $\begin{array}{l}\text { Reshaping } \\
\text { product/services } \\
\text { offering }\end{array}$ & Earthquakes & $\begin{array}{l}\text { COVID } \\
-19\end{array}$ \\
\hline $\mathrm{ROBI}$ & $\begin{array}{l}\text { More focus on } \\
\text { customer service } \\
\text { and continuous } \\
\text { communication to } \\
\text { satisfy customer } \\
\text { demands. }\end{array}$ & $\begin{array}{l}\text { Increase } \\
\text { e-commerce } \\
\text { presence thought } \\
\text { online stores. }\end{array}$ & $\begin{array}{l}\text { Emails, phone } \\
\text { calls and social } \\
\text { media. }\end{array}$ & $\begin{array}{l}\text { "Although distribution and } \\
\text { logistics have remained } \\
\text { the same, continuous } \\
\text { and more detailed } \\
\text { communication with } \\
\text { distributors has been } \\
\text { strengthened." }\end{array}$ & $\begin{array}{l}\text { Daily updated } \\
\text { reports with } \\
\text { different } \\
\text { departments due } \\
\text { to the increasing } \\
\text { demand after } \\
\text { events. }\end{array}$ & NO & YES \\
\hline
\end{tabular}


Table A2. Interview responses summary: resilience CRM matrix (continuation)

\begin{tabular}{|c|c|c|c|c|c|c|c|}
\hline BECO & $\begin{array}{l}\text { Education and } \\
\text { orientation about } \\
\text { the use, benefits, } \\
\text { components and } \\
\text { other cosmetic } \\
\text { attributes. }\end{array}$ & $\begin{array}{l}\text { Introducing private } \\
\text { labels cosmetics } \\
\text { le.g. skin care make- } \\
\text { upsl for baby boomer } \\
\text { generation through } \\
\text { social medias and } \\
\text { advertising on } \\
\text { company's webpage. }\end{array}$ & $\begin{array}{l}\text { Internet websites, } \\
\text { social media } \\
\text { platforms-Facebook, } \\
\text { Instagram-to receive } \\
\text { and process customer } \\
\text { requests instantly. }\end{array}$ & $\begin{array}{l}\text { Delivery } 24 / 7 \text { using } \\
\text { USPS services to } \\
\text { domestic and foreign } \\
\text { market customers } \\
\text { (retailers such as } \\
\text { community pharmacies } \\
\text { and large retailers such } \\
\text { as Wal-Mart). }\end{array}$ & $\begin{array}{l}\text { Prioritizing company's } \\
\text { cosmetics lines (e.g., } \\
\text { nails enamels and } \\
\text { related products, and } \\
\text { face foundation and } \\
\text { powders), and delivering } \\
\text { without any minimum } \\
\text { amount of products. }\end{array}$ & YES & YES \\
\hline MAFA & $\begin{array}{l}\text { Inventory } \\
\text { availability to } \\
\text { ensure nonstop } \\
\text { delivery process to } \\
\text { clients. }\end{array}$ & $\begin{array}{l}\text { Incrementing } \\
\text { recruiting of labor- } \\
\text { intensive workforce } \\
\text { to plant crops in } \\
\text { newly bought land. }\end{array}$ & $\begin{array}{l}\text { Mobile phone calls, } \\
\text { Internet websites, } \\
\text { social media } \\
\text { platforms-Facebook, } \\
\text { Instagram-to receive } \\
\text { and process customer } \\
\text { requests instantly. }\end{array}$ & $\begin{array}{l}\text { Implementing safety } \\
\text { and security protocol to } \\
\text { guarantee employees } \\
\text { sanitary security inside } \\
\text { the manufacturing } \\
\text { facilities, as well as } \\
\text { in the logistics and } \\
\text { distribution processes. }\end{array}$ & $\begin{array}{l}\text { Introducing a new } \\
\text { safety and security } \\
\text { protocol for harvesting, } \\
\text { manufacturing } \\
\text { and supply chain } \\
\text { management to maintain } \\
\text { safe organizational } \\
\text { behavior. }\end{array}$ & NO & YES \\
\hline FAPRO & $\begin{array}{l}\text { Immediate } \\
\text { delocalization of } \\
\text { facilities (6 days } \\
\text { after earthquakes) } \\
\text { within the } \\
\text { municipality to } \\
\text { avoid customer } \\
\text { losses. } \\
\text { Payment of salaries } \\
\text { to employees } \\
\text { during lockdown } \\
\text { period (6 days). } \\
\text { Introduction of } \\
\text { new products and } \\
\text { services. }\end{array}$ & $\begin{array}{l}\text { In the case of } \\
\text { COVID-19, targeted } \\
\text { new customers: } \\
\text { government, } \\
\text { microenterprises, } \\
\text { physicians, } \\
\text { cooperatives, gas } \\
\text { stations, auto } \\
\text { dealers, optic } \\
\text { centers, and foreign } \\
\text { clients in USA. }\end{array}$ & $\begin{array}{l}\text { Traditional methods: } \\
\text { billboard in the } \\
\text { municipality street, } \\
\text { announcements } \\
\text { in door front of } \\
\text { the new facility, } \\
\text { Facebook, webpage, } \\
\text { loudspeakers, and } \\
\text { phone calls to clients. } \\
\text { Faster submission of } \\
\text { documents to secure } \\
\text { operations in the new } \\
\text { facility. }\end{array}$ & $\begin{array}{l}\text { For both disruptive } \\
\text { events, the logistics was } \\
\text { reverted: clients pick } \\
\text { up the merchandise } \\
\text { directly to providers } \\
\text { instead of delivered by } \\
\text { carriers of providers. } \\
\text { Daily delivery } \\
\text { perishable and } \\
\text { medicine to client's } \\
\text { door to door to closed } \\
\text { municipalities and in } \\
\text { some municipalities of } \\
\text { the metro zone such } \\
\text { as San Juan, Cayey, } \\
\text { Caguas. }\end{array}$ & $\begin{array}{l}\text { Decreasing refrigerated } \\
\text { products and the } \\
\text { introduction of mass } \\
\text { inventory of security } \\
\text { health care goods } \\
\text { lglobes, hand sanitizer, } \\
\text { masks, alcohol, medical } \\
\text { disposable uniforms, and } \\
\text { caps). } \\
\text { Inclusion of electronic } \\
\text { payment thought cell } \\
\text { phone (ATH Móvill. } \\
\text { Daily delivery process } \\
\text { door-to-door to } \\
\text { commercial and end } \\
\text { consumers. }\end{array}$ & YES & YES \\
\hline FAVE & $\begin{array}{l}\text { Non-perishable } \\
\text { edible products } \\
\text { were added to the } \\
\text { product portfolio. }\end{array}$ & $\begin{array}{l}\text { New customers } \\
\text { from nearby } \\
\text { municipalities } \\
\text { (Ponce, Peñuelas, } \\
\text { Yauco), and from } \\
\text { other pharmacies. }\end{array}$ & $\begin{array}{l}\text { Intensive use of } \\
\text { social media, mainly } \\
\text { Facebook, phone } \\
\text { calls and radio } \\
\text { advertisement } \\
\text { and informational } \\
\text { signs in the store } \\
\text { to communicate to } \\
\text { clients pharmacy } \\
\text { hours of operation, } \\
\text { and other services. }\end{array}$ & $\begin{array}{l}\text { Agreements only with } \\
10 \% \text { of providers; those } \\
\text { that were able to supply } \\
\text { regularly with expected } \\
\text { goods, and quality } \\
\text { of services (Cardinal } \\
\text { Health and Drogeria } \\
\text { Betances). They deliver } \\
\text { overnight. }\end{array}$ & $\begin{array}{l}\text { Reconfiguration of } \\
\text { the operation hours, } \\
\text { customer service and } \\
\text { new products according } \\
\text { to the new health and } \\
\text { security rules. } \\
\text { Including in the inventory } \\
\text { cleaning products, } \\
\text { chlorine, disposable } \\
\text { plates and cutlery, } \\
\text { masks, gloves, hand } \\
\text { sanitizer, etc. } \\
\text { Thesystem for processing } \\
\text { medical prescriptions } \\
\text { by email was integrated } \\
\text { permanently and without } \\
\text { the requirement of } \\
\text { customer signature. } \\
\text { Non-perishable food } \\
\text { was discarded from } \\
\text { the inventory after } \\
\text { the reopening of } \\
\text { supermarkets and and } \\
\text { convenience stores. }\end{array}$ & YES & YES \\
\hline ESTRE & $\begin{array}{l}\text { Business and home } \\
\text { delivery services } \\
\text { (breakfast and } \\
\text { lunches). } \\
\text { Space for } \\
\text { minimarket product } \\
\text { offerings. }\end{array}$ & $\begin{array}{l}\text { New clients } \\
\text { from other } \\
\text { towns increased } \\
\text { significantly during } \\
\text { the earthquakes } \\
\text { from } 1,500 \text { to } 2,000 \\
\text { clients per day. } \\
\text { With the COVID-19 } \\
\text { lockdown, the face- } \\
\text { to-face customer } \\
\text { input has been } \\
\text { reduced from } 500 \text { to } \\
700 \text { per day, which is } \\
\text { compensated for by } \\
\text { service deliveries. }\end{array}$ & $\begin{array}{l}\text { Using Facebook } \\
\text { and phone calls for } \\
\text { delivery services. }\end{array}$ & $\begin{array}{l}\text { Adjustments were } \\
\text { made in the opening } \\
\text { hours from 5:00 am } \\
\text { to } 6: 00 \mathrm{pm} \text { (before the } \\
\text { lockdown it was from } \\
\text { 5:00 am to 10:00 pm). } \\
\text { The number of } \\
\text { customers, distance, } \\
\text { time within the } \\
\text { bakery and protection } \\
\text { requirements (masks } \\
\text { and gloves for } \\
\text { employees and masks } \\
\text { for customers) were } \\
\text { reconfigured. }\end{array}$ & $\begin{array}{l}\text { Business and home } \\
\text { delivery of breakfasts } \\
\text { and lunches were } \\
\text { included as a new } \\
\text { service. } \\
\text { The introduction of a } \\
\text { minimarket within the } \\
\text { bakery. }\end{array}$ & YES & YES \\
\hline
\end{tabular}




\section{References}

Albuquerque, R., Koskinen, Y., Yang, S., \& Zhang, C. (2020). Resiliency of environmental and social stocks: An analysis of the exogenous COVID-19 market crash. The Review of Corporate Finance Studies, 9(3), 593-621. https://doi.org/10.1093/rcfs/cfaa011

Anionwu, C., Nwaizugbo, I. C., \& Ukenna, S. (2014). Assessment of post environmental disaster on the marketing activities of small scale enterprises in South-South Nigeria. Journal of Business Behavioral Sciences, 26(3), 79-88. http://eprints.covenantuniversity.edu.ng/10064/1/3.pdf

Ascarza, E., Ebbes, P., Netzer, O., \& Danielson, M. (2017). Beyond the target customer: Social effects of customer relationship management campaigns. Journal of Marketing Research, 54(3), 347363. https://doi.org/10.1509/jmr.15.0442

Back, A., Tulsky, J. A., \& Arnold, R. M. (2020). Communication skills in the age of COVID-19. Annals of Internal Medicine, 172(11), 759-760. https://doi.org/10.7326/M20-1376

Baker, S. M. (2009). Vulnerability and resilience in natural disasters: A marketing and public policy perspective. Journal of Public Policy \& Marketing, 28(1), 114-123. https://doi.org/10.1509/jppm.28.1.114

Baker, S. M., Hill, R. P., Baker, C. N., \& Mittelstaedt, J. D. (2015). Improvisational provisioning in disaster: The mechanisms and meanings of ad hoc marketing exchange systems in community. Journal of Macromarketing, 35(3), 334-352. https://doi.org/10.1177\%2F0276146714550994

Biggs, D., Hall, C. M., \& Stoeckl, N. (2012). The resilience of formal and informal tourism enterprises to disasters: reef tourism in Phuket, Thailand. Journal of Sustainable Tourism, 20(5), 645-665. https://doi.org/10.1080/09669582.2011.630080

Cambra-Fierro, J. J., Centeno, E., Olavarria, A., \& Vazquez-Carrasco, R. (2017). Success factors in a CRM strategy: Technology is not all. Journal of Strategic Marketing, 25(4), 316-333. https://doi.org/10.1080/0965254X.2016.1148760

Christopher, M., \& Lee, H. (2004). Mitigating supply chain risk through improved confidence. International Journal of Physical Distribution \& Logistics Management, 34(5), 388-396. https://doi.org/10.1108/09600030410545436

Liu, C., \& Black, W. (2011). Post-disaster consumer coping: Consumption adjustment. In Z. Yi, J. J. Xiao, J. Cotte, \& L. Price (Eds.), AP - AsiaPacific Advances in Consumer Research Volume 9 (pp. 214-221). Duluth: Association for Consumer Research.

Crick, J. M. (2020). Qualitative research in marketing: What can academics do better? Journal of Strategic Marketing, 1-40. https://doi.org/10.1080/0965254X.2020.1743738

Debnath, R., Datta, B., \& Mukhopadhyay, S. (2016). Customer relationship management theory and research in the new millennium: Directions for future research. Journal of Relationship Marketing, 15(4), 299325. https://doi.org/10.1080/15332667.2016.1209053

Donthu, N., \& Gustafsson, A. (2020). Effects of COVID-19 on business and research. Journal of Business Research, 117, 284-289. https://doi.org/10.1016/j.jbusres.2020.06.008

Eggers, F. (2020). Masters of disasters? Challenges and opportunities for SMEs in times of crisis. Journal of Business Research, 116, 199208. https://doi.org/10.1016/j.jbusres.2020.05.025

Folke, C., Carpenter, S. R., Walker, B., Scheffer, M., Chapin, T., \& Rockström, J. (2010). Resilience thinking: Integrating resilience, adaptability and transformability. Ecology and Society, 15(4), 20.

Forbes, N. (2009). Contingency planning for earthquakes in Asia. Journal of Business Continuity \& Emergency Planning, 3(4), 356-367.

Freeman, J., \& Hancock, L. (2017). Energy and communication infrastructure for disaster resilience in rural and regional Australia. Regional Studies, 51(6), 933-944. https://doi.org/10.1080/00343404.2016.1146403

Gasser, P., Lustenberger, P., Cinelli, M., Kim, W., Spada, M., Burgherr, P., Hirschberg, S., Stojadinovic, B. \& Sun, T.Y. (2019). A review on resilience assessment of energy systems. Sustainable and Resilient Infrastructure. https://doi.org/10.1080/23789689.2019.1610600
Groenland, E. (2014). Employing the matrix method as a tool for the analysis of qualitative research data in the business domain. SSRN Electronic Journal. https://dx.doi.org/10.2139/ssrn.2495330

Gu, X., Ying, S., Zhang, W., \& Tao, Y. (2020). How do firms respond to COVID-19? First evidence from Suzhou, China. Emerging Markets Finance and Trade, 56(10), 2181-2197. https://doi.org/10.1080/1540496X.2020.1789455

Hong, P., Huang, C., \& Li, B. (2012). Crisis management for SMEs: insights from a multiple-case study. International Journal of Business Excellence, 5(5), 535-553. https://doi.org/10.1504/IJBEX.2012.048802

Hussein, A. (2009). The use of triangulation in social sciences research: Can qualitative and quantitative methods be combined. Journal of Comparative Social Work, 1(1), 1-12.

Javalgi, R. R. G., Martin, C. L., \& Young, R. B. (2006). Marketing research, market orientation and customer relationship management: a framework and implications for service providers. Journal of Services Marketing, 20(1), 12-23.

https://doi.org/10.1108/08876040610646545

Kay, E., Brown, C., Hatton, T., Stevenson, J. R., Seville, E., \&Vargo, J. (2019). Business recovery from disaster: A research update for practitioners. The Australasian Journal of Disaster and Trauma Studies, 23(2), 83-89.

Kotler, P. \& Keller, K. L. (2016). Marketing management (15th ed.). Londres: Pearson Education Limited.

Kumar, V. \& Reinartz, W. (2018). Future of CRM. In: Customer Relationship Management. Springer Texts in Business and Economics (pp. 385 404). Berlin: Springer.

https://doi.org/10.1007/978-3-662-55381-7_18

Liguori, E.W. \& Pittz, T.G. (2020). Strategies for small business: Surviving and thriving in the era of COVID-19. Journal of the International Council for Small Business, 1(2), 106-110. https://doi.org/10.1080/26437015.2020.1779538

Lozada-Contreras, F., Orengo Serra, K. L., \& Sánchez-Jauregui, M. (2021). Adaptive customer relationship management contingency model under disruptive events. Journal of Advances in Management Research, ahead-of-print. https://doi.org/10.1108/JAMR-12-2020-0347

Martinelli, E., Tagliazucchi, G., \& Marchi, G. (2018). The resilient retail entrepreneur: Dynamic capabilities for facing natural disasters. International Journal of Entrepreneurial Behavior and Research, 24(7), 1222-1243. https://doi.org/10.1108/IJEBR-11-2016-0386

Miles, M. P., Lewis, G. K., Hall-Phillips, A., Morrish, S. C., Gilmore, A. \& Kasouf, C. J. (2016). The influence of entrepreneurial marketing processes and entrepreneurial self-efficacy on community vulnerability, risk, and resilience. Journal of Strategic Marketing, 24(1), 34-46. https://doi.org/10.1080/0965254X.2015.1035038

Morrish, S. C. \& Jones, R. (2019). Post-disaster business recovery: An entrepreneurial marketing perspective. Journal of Business Research, 113, 83-92. https://doi.org/10.1016/j.jbusres.2019.03.041

$\mathrm{Ng}, \mathrm{F} ., \&$ Aksoy, M. A. (2008). Who are the net food importing countries? The World Bank.

Organisation for Economic Co-operation and Development. (2020). The territorial impact of COVID-19: Managing the crisis across levels of government. Retrieved from: https://read.oecd-ilibrary.org/ view/?ref=128_128287-5agkkojaaa\&title=The-territorial-impactof-COVID-19-managing-the-crisis-across-levels-of-government

Ozanne, J. L. \& Ozanne, L. K. (2014). Community Resiliency in the Aftermath of the New Zealand Earthquakes. ACR North American Advances, 42, 7-11. https://www.acrwebsite.org/volumes/1018042/ volumes/v42/NA-42

Pantano, E., Pizzi, G., Scarpi, D., \& Dennis, C. (2020). Competing during a pandemic? Retailers' ups and downs during the COVID-19 outbreak. Journal of Business Research, 116, 209-213. https://doi.org/10.1016/j.jbusres.2020.05.036

Pelling, M., \& Uitto, J. I. (2001). Small island developing states: natural disaster vulnerability and global change. Global Environmental Change Part B: Environmental Hazards, 3(2), 49-62. https://doi.org/10.3763/ehaz.2001.0306 
Rahimi, I. \& Berman, U. (2009). Building a CSF framework for CRM implementation. Journal of Database Marketing \& Customer Strategy Management, 16(4), 253-265.

https://doi.org/10.1057/dbm.2009.29

Ramos Segarra, C. G. (2020, August 18). 30 percent of Puerto Rico businesses could close permanently. The Weekly Journal. Retrieved from: https://www.theweeklyjournal.com/business/30-percentof-puerto-rico-businesses-could-close-permanently/article a1644922-e15c-11ea-9b9f-5ba8999dd5aa.html

Richards, K. A. \& Jones, E. (2008). Customer relationship management: Finding value drivers. Industrial Marketing Management, 37(2), 120 130. https://doi.org/10.1016/j.indmarman.2006.08.005

Shen, H., Fu, M., Pan, H., Yu, Z., \& Chen, Y. (2020). The impact of the COVID-19 pandemic on firm performance. Emerging Markets Finance and Trade, 56(10), 2213-2230. https://doi.org/10.1080/1540496X.2020.1785863

Sheth, J. (2020). Impact of COVID-19 on consumer behavior: Will the old habits return or die? Journal of Business Research, 117, 280-283. https://doi.org/10.1016/j.jbusres.2020.05.059

Sigala, M. (2020). Tourism and COVID-19: Impacts and implications for advancing and resetting industry and research. Journal of Business Research, 117, 312-321. https://doi.org/10.1016/j.jbusres.2020.06.015

United Nations. (2020). Policy brief: The impact of COVID-19 on Latin America and the Caribbean. Retrieved from: https://www.un.org/ sites/un2.un.org/files/sg_policy_brief_covid_lac.pdf

USGS. (n.d.). What are the long-term effects of climate change? Retrieved from: https://www.usgs.gov/faqs/what-are-long-termeffects-climate-change-1?qt-news_science_products $=3$ \#qtnews_science_products
Van Der Elst, N., Hardebeck, J. L. \& Michael, A. J. (2020). Potential duration of aftershocks of the 2020 southwestern Puerto Rico earthquake (No. 2020-1009). US Geological Survey. https://doi.org/10.3133/ofr20201009

Vargas, J., \& González, D. (2016). Model to assess supply chain resilience. International Journal of Safety and Security Engineering, 6(2), 282-292. https://doi.org/10.2495/SAFE-V6-N2-282-292

Wakabayashi, J. L. \& Merzthal, J. (2015). Directrices para la implementación de un modelo de gestión de la relación con el cliente en el sector industrial: caso DAMERA. Estudios Gerenciales, 31(137), 455-462. https://doi.org/10.1016/j.estger.2015.09.001

Waldman, R. (2019). Natural and human-made disasters. The CDC field epidemiology manual. Retrieved from: https://www.cdc.gov/eis/ field-epi-manual/chapters/Natural-Human-Disasters.html

Wang, Y., Hong, A., Li, X., \& Gao, J. (2020). Marketing innovations during a global crisis: A study of China firms' response to COVID-19. Journal of Business Research, 116, 214-220. https://doi.org/10.1016/j.jbusres.2020.05.029

World Health Organization. (2020). Coronavirus disease (COVID-19) weekly epidemiological update and weekly operational update. Retrieved from: https://www.who.int/emergencies/diseases/ novel-coronavirus-2019/situation-reports.

Williams, P., Ashill, N., \& Naumann, E. (2017). Toward a contingency theory of CRM adoption. Journal of Strategic Marketing, 25(5-6), 454-474. https://www.tandfonline.com/doi/abs/10.1080/096525 $4 X .2016 .1149211$ 